\title{
Phytoremediation of heavy metals from paper mill effluent soil using Croton sparsiflorus
}

\author{
B. Ashok Kumar ${ }^{1, \star}$, S. Jothiramalingam ${ }^{2}$, S. K. Thiyagarajan ${ }^{2}$, \\ T. Hidhayathullakhan ${ }^{3}$, R. Nalini ${ }^{4}$ \\ ${ }^{1}$ Research Scholar, Khadir Mohideen College, Adirampattinam - 614 701, \\ Thanjavur - (Dt), Tamil Nadu, India \\ ${ }^{2}$ P.G. and Research Department of Chemistry, A.V.V.M. Sri Pushpam College (Autonomous), \\ Poondi - 613 503, Thanjavur - (Dt), Tamil Nadu, India \\ ${ }^{3}$ Department of Chemistry, Khadir Mohideen College, Adirampattinam - 614 701, \\ Thanjavur - (Dt), Tamil Nadu, India \\ ${ }^{4}$ Department of Chemistry, Periyar Maniammai University, \\ Vallam - Thanjavur (Dt), Tamil Nadu, India \\ *E-mail address: balaashok.kumar@gmail.com
}

\begin{abstract}
Effluents from industries contain appreciable amount of metallic cations like zinc, copper, iron, manganese, lead and cadmium. Release of heavy metal without proper treatment poses a significant threat to public health because of its persistence biomagnifications and accumulation in food chain. To reduce metal pollution problems many processes have been developed for the treatment and disposal of metal containing wastes. Certain plants have the ability to accumulate heavy metals such as $\mathrm{Pb}, \mathrm{Cr}, \mathrm{Cd}$ and $\mathrm{Zn}$. At present, phytoremediation of metals may be approaching commercialization. Hence, possibility can be explored to remove heavy metal load, present even in low concentration, in waste water of paper mill effluent soil by using Croton sparsiflorus.
\end{abstract}

Keywords: Phytoremediation; Heavy metals; Effluent soil; Croton sparsiflorus

\section{INTRODUCTION}

Industrial or domestic effluent is mostly used for the fertigation of agricultural crops, mainly in urban and per urban regions, due to its easy availability, disposal problems and scarcity of fresh water [1,2]. Irrigation with effluents is known to contribute significantly to the heavy metals content of soil as well as crop plants [3-5]. Heavy metals are very harmful because of their non-biodegrable nature, long biological half-lives and their potential to accumulate in different body parts [6-8]. Most of the heavy metals are extremely toxic because of their solubility in water $[3,9,10]$. The major short comings of the conventional treatments are low efficiency at low concentration of heavy metals, expensive handling and safe disposal of toxic sludge [11].

India has 666 pulp and paper mills, out of which 632 mills are agro-residue based mills $[12,13]$. They generate a huge amount of wastewater having high biological oxygen demand 
(BOD) and chemical oxygen demand (COD) values [14,15]. The various elements introduced through pulp mill wastewater irrigation not only affect the crop growth and soil properties but also their relative mobility in the soil profile $[16,17]$. Pulp and paper mill is a major industrial sector utilizing a huge amount of lignocellulogic materials and water during the manufacturing process, and release chlorinated lignosulphonic acids, chlorinated resin acids, chlorinated phenols and chlorinated hydrocarbon in the effluent [18].

In this regard, phytoremediation or plant - based cleanup, have generated much interest as effective low-cost and environmentally-friendly technologies for the clean-up of a broad spectrum of hazardous organic and inorganic pollutants [19]. The success of phytoremediation depends on the availability of plant species - ideally those native to the region of interestable to tolerate and accumulate high concentrations of heavy metals [20]. Phytoremediation technologies is an emerging technology for the remediation of metal contaminated soils. It can be defined as "use of green plants and their associated microbiota, soil amendments and agronomic techniques to remove, contain or render harmless the environmental contaminants [21]. The heavy metal accumulation efficiency of the Croton sparsiflorus plant and also effect of addition of biosolids like vermicompost on the bioaccumulation efficiency of the plant have been investigated and the concentration of heavy metals from effluent soil was also evaluated (Figure 1).

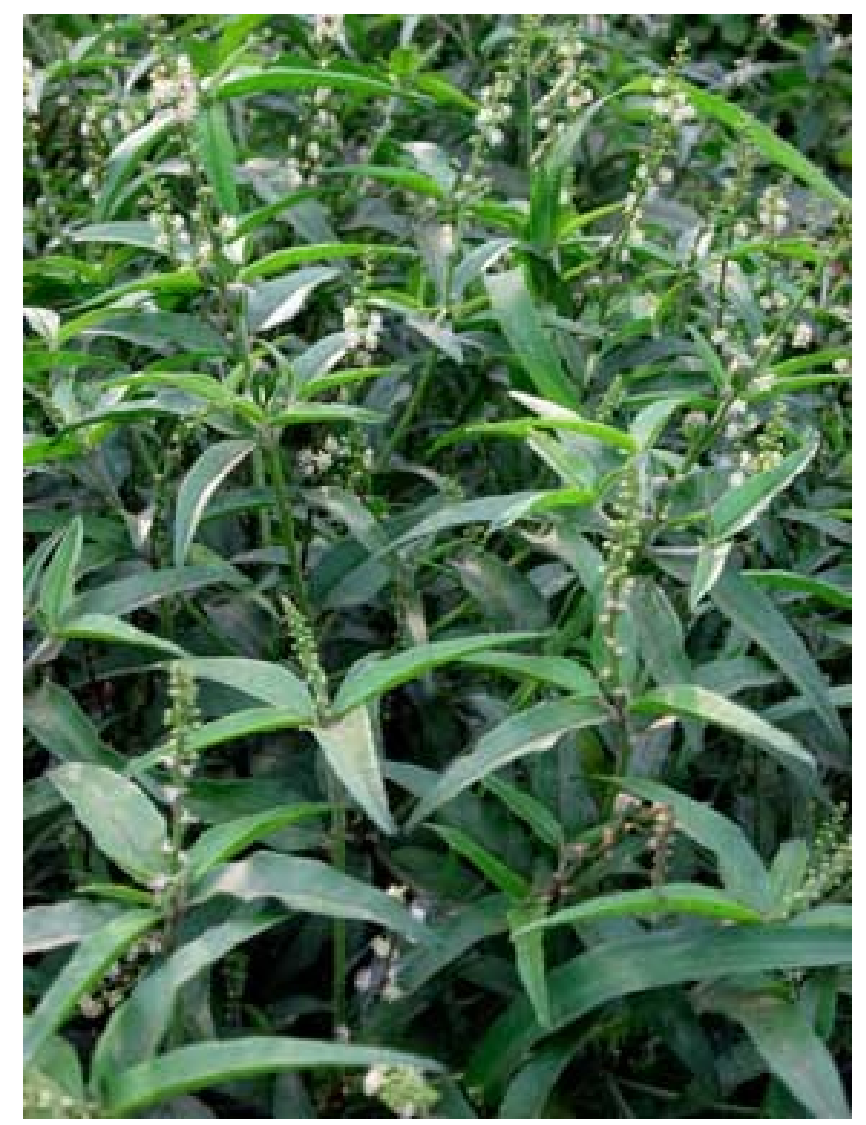

Figure 1. Croton sparsiflorus. 


\section{MATERIALS AND METHODS}

\section{1. Collection of materials}

The garden soils are gathered from nearest places. The effluent is collected from paper mill located at Solagampatti, Thanjavur, Tamilnadu. Croton sparsiflorus seeds are collected from this plant Edavakkudi, Poondi, Thanjavur, Tamil nadu. Vermicompost was prepared with cow dung using earthworm species Eurdius euginae. Seeds were germinated in experimental pots and watered. On fifteenth, thirtieth, forty fifth and sixtieth days the plants were harvested from pots and the concentration of heavy metals Chromium $(\mathrm{Cr})$, Lead $(\mathrm{Pb})$, Cadmium (Cd) and Zinc (Zn) of the samples were noted.

\section{2. Experimental setup}

The seedlings were exposed to different concentrations of heavy metal chromium to find the toxicity. Chromium at high concentrations of 200 and $300 \mathrm{mg} / \mathrm{kg}$ showed high toxicity that the plants died. (Revathi et al., 2011). The various experimental setup used for the present study are listed below:

Table 1. Experimental setup.

\begin{tabular}{|c|c|c|c|c|c|c|}
\hline S. No. & Pot No. & GS (kg) & $\begin{array}{c}\text { CS Seeds } \\
(\mathbf{g})\end{array}$ & $\begin{array}{c}\text { VC } \\
\mathbf{( k g )}\end{array}$ & $\begin{array}{c}\text { PME } \\
(\mathbf{m l})\end{array}$ & $\begin{array}{c}\text { Plant } \\
\text { harvested } \\
\text { (days) }\end{array}$ \\
\hline 1 & A1 & 1 & 2 & - & 50 & 15 \\
\hline 2 & A2 & 1 & 2 & - & 50 & 30 \\
\hline 3 & A3 & 1 & 2 & - & 50 & 45 \\
\hline 4 & A4 & 1 & 2 & - & 50 & 60 \\
\hline 5 & B1 & $1 / 2$ & 2 & $1 / 2$ & 50 & 15 \\
\hline 6 & B2 & $1 / 2$ & 2 & $1 / 2$ & 50 & 30 \\
\hline 7 & B3 & $1 / 2$ & 2 & $1 / 2$ & 50 & 45 \\
\hline 8 & B4 & $1 / 2$ & 2 & $1 / 2$ & 50 & 60 \\
\hline 9 & C1 & 1 & 2 & - & 100 & 15 \\
\hline 10 & C2 & 1 & 2 & - & 100 & 30 \\
\hline 11 & C3 & 1 & 2 & - & 100 & 45 \\
\hline 12 & C4 & 1 & 2 & - & 100 & 60 \\
\hline 13 & D1 & $1 / 2$ & 2 & $1 / 2$ & 100 & 15 \\
\hline 14 & D2 & $1 / 2$ & 2 & $1 / 2$ & 100 & 30 \\
\hline 15 & D3 & $1 / 2$ & 2 & $1 / 2$ & 100 & 45 \\
\hline 16 & D4 & $1 / 2$ & 2 & $1 / 2$ & 100 & 60 \\
\hline 17 & E1 & 1 & 2 & - & 200 & 15 \\
\hline
\end{tabular}




\begin{tabular}{|c|c|c|c|c|c|c|}
\hline 18 & E2 & 1 & 2 & - & 200 & 30 \\
\hline 19 & E3 & 1 & 2 & - & 200 & 45 \\
\hline 20 & E4 & 1 & 2 & - & 200 & 60 \\
\hline 21 & F1 & $1 / 2$ & 2 & $1 / 2$ & 200 & 15 \\
\hline 22 & F2 & $1 / 2$ & 2 & $1 / 2$ & 200 & 30 \\
\hline 23 & F3 & $1 / 2$ & 2 & $1 / 2$ & 200 & 45 \\
\hline 24 & F4 & $1 / 2$ & 2 & $1 / 2$ & 200 & 60 \\
\hline
\end{tabular}

GS - Garden Soil, CS - Croton Sparsiflorus,

VC - VermiCompost, PME - Paper Mill Effluent

\section{3. Heavy metal analysis of soil samples}

Soil samples of each pot were air dried, crushed and pass through $0.2 \mathrm{~mm}$ sieve and stored in Zip lock covers for analysis. Heavy metals present in all the samples were analyzed by AAS (Atomic Absorption Spectroscopy).

\section{RESULTS AND DISCUSSION}

The concentration of heavy metals are varies in paper mill effluent $(\mathrm{Pb}>\mathrm{Zn}>\mathrm{Cr}>$ $\mathrm{Cd})$. Heavy metals concentration are decreases largely in B, D and F type (15-60 days) pots, because it consists of vermicompost which is used to growing plant and accumulation of heavy metals. So, the well growing plants which accumulate heavy metals easily than other pots (A, C and E type). Finally, excess amount of heavy metals in soil are remediated by combination of vermicompost with garden soil.

Physico - chemical characteristics of the effluent collected from the paper industry is given below:

Table 2. Physico - chemical characteristics of the effluent collected from the paper industry.

\begin{tabular}{|c|c|c|}
\hline S. No & Name of the parameter & Sample details \\
\hline \multicolumn{3}{|c|}{ Physical parameter } \\
\hline 1 & Colour & $>1$ hue \\
\hline 2 & Odour & Unpleasant \\
\hline 3 & Turbidity & $105 \mathrm{NTU}$ \\
\hline 4 & Total dissolved solids & 1453 \\
\hline 5 & $\mathrm{pH}$ & 7.89 \\
\hline 6 & Electrical conductivity $\left(\mathrm{dsm}^{-1}\right)$ & 2.27 \\
\hline 7 & BOD $(\mathrm{mg} / \mathrm{l})$ & 129 \\
\hline
\end{tabular}




\begin{tabular}{|c|c|c|}
\hline 8 & COD (mg/l) & 45 \\
\hline \multicolumn{3}{|c|}{ Heavy metals } \\
\hline 9 & Zinc (mg/l) & 3.46 \\
\hline 10 & Chromium (mg/l) & 2.53 \\
\hline 11 & Lead (mg/l) & 6.28 \\
\hline 12 & Cadmium (mg/l) & 1.39 \\
\hline
\end{tabular}

Table 3. Heavy metal concentrations in various soil samples.

\begin{tabular}{|c|c|c|c|c|c|c|}
\hline S. No & Pot No. & $\mathrm{Cr}$ & Cd & $\mathbf{P b}$ & $\mathbf{Z n}$ & $\begin{array}{c}\text { Reduction of } \\
\text { concentration } \\
\text { (Days) }\end{array}$ \\
\hline 1 & A1 & 2.48 & 1.35 & 5.89 & 3.35 & 15 \\
\hline 2 & A2 & 2.19 & 1.29 & 4.92 & 2.98 & 30 \\
\hline 3 & A3 & 1.56 & 1.09 & 3.50 & 2.56 & 45 \\
\hline 4 & A4 & 1.35 & 0.85 & 2.89 & 2.31 & 60 \\
\hline 5 & B1 & 2.40 & 1.30 & 5.48 & 3.02 & 15 \\
\hline 6 & B2 & 1.30 & 0.95 & 4.30 & 2.89 & 30 \\
\hline 7 & B3 & 0.09 & 0.15 & 2.35 & 0.64 & 45 \\
\hline 8 & B4 & 0.04 & 0.10 & 2.02 & 0.59 & 60 \\
\hline 9 & $\mathrm{C} 1$ & 2.51 & 1.29 & 5.92 & 3.38 & 15 \\
\hline 10 & $\mathrm{C} 2$ & 2.29 & 1.18 & 4.69 & 3.22 & 30 \\
\hline 11 & $\mathrm{C} 3$ & 1.95 & 0.98 & 3.75 & 2.85 & 45 \\
\hline 12 & $\mathrm{C} 4$ & 1.56 & 0.89 & 2.76 & 2.69 & 60 \\
\hline 13 & D1 & 2.39 & 1.32 & 6.18 & 3.09 & 15 \\
\hline 14 & D2 & 2.01 & 0.98 & 5.59 & 2.86 & 30 \\
\hline 15 & D3 & 0.10 & 0.29 & 2.28 & 0.75 & 45 \\
\hline 16 & D4 & 0.03 & 0.19 & 1.98 & 0.62 & 60 \\
\hline 17 & E1 & 2.50 & 1.34 & 5.65 & 3.39 & 15 \\
\hline 18 & E2 & 2.34 & 1.28 & 4.85 & 3.25 & 30 \\
\hline 19 & E3 & 1.93 & 1.19 & 3.92 & 2.89 & 45 \\
\hline 20 & E4 & 1.65 & 0.95 & 2.91 & 2.55 & 60 \\
\hline 21 & $\mathrm{~F} 1$ & 2.46 & 1.35 & 6.15 & 3.15 & 15 \\
\hline 22 & $\mathrm{~F} 2$ & 2.15 & 0.85 & 5.68 & 2.82 & 30 \\
\hline 23 & F3 & 0.91 & 0.59 & 3.56 & 0.85 & 45 \\
\hline 24 & $\mathrm{~F} 4$ & 0.09 & 0.45 & 1.91 & 0.65 & 60 \\
\hline
\end{tabular}




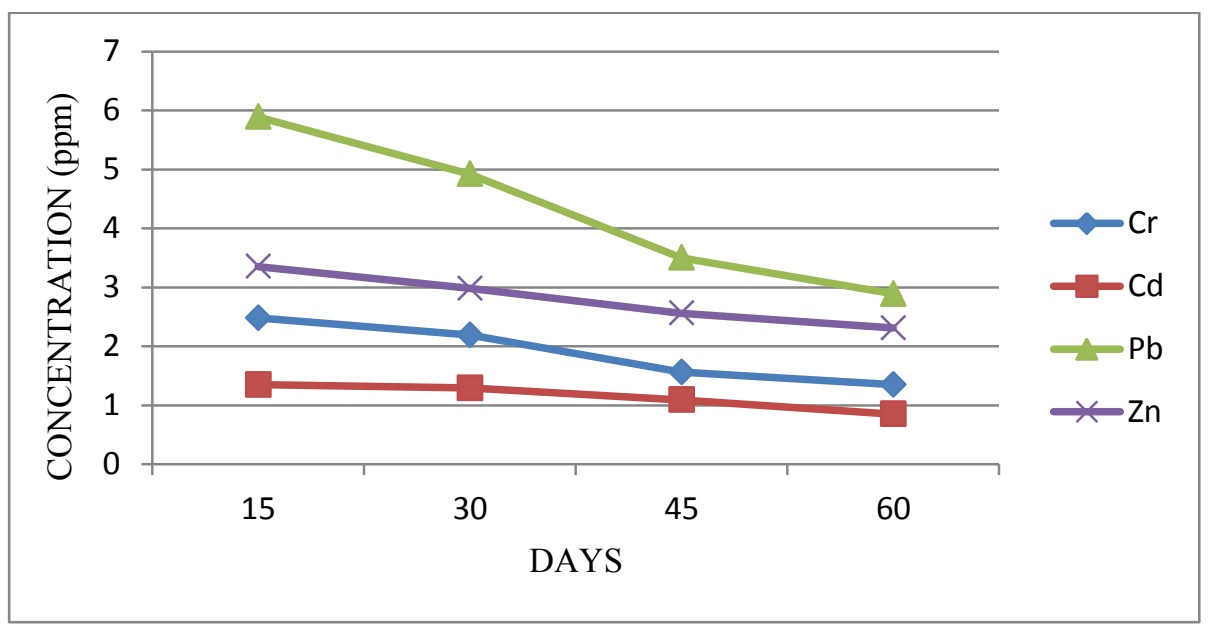

Fig. 1. Reduction of heavy metal concentrations in pot A1 to A4.

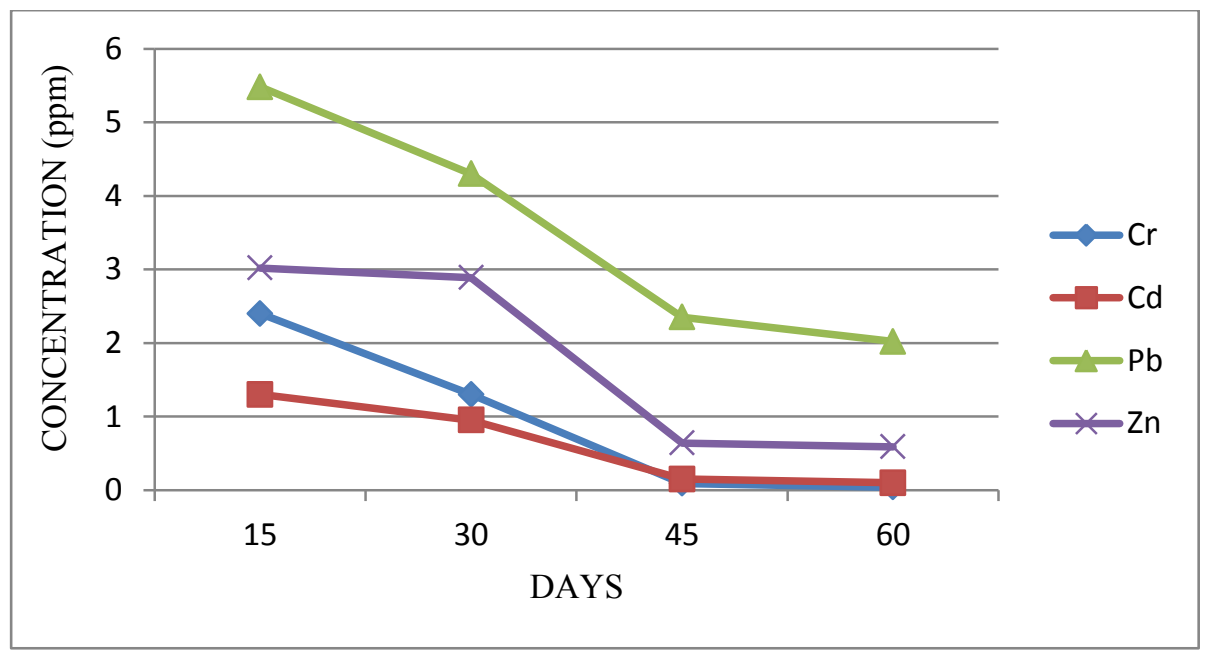

Fig. 2. Reduction of heavy metal concentrations in pot B1 to B4.

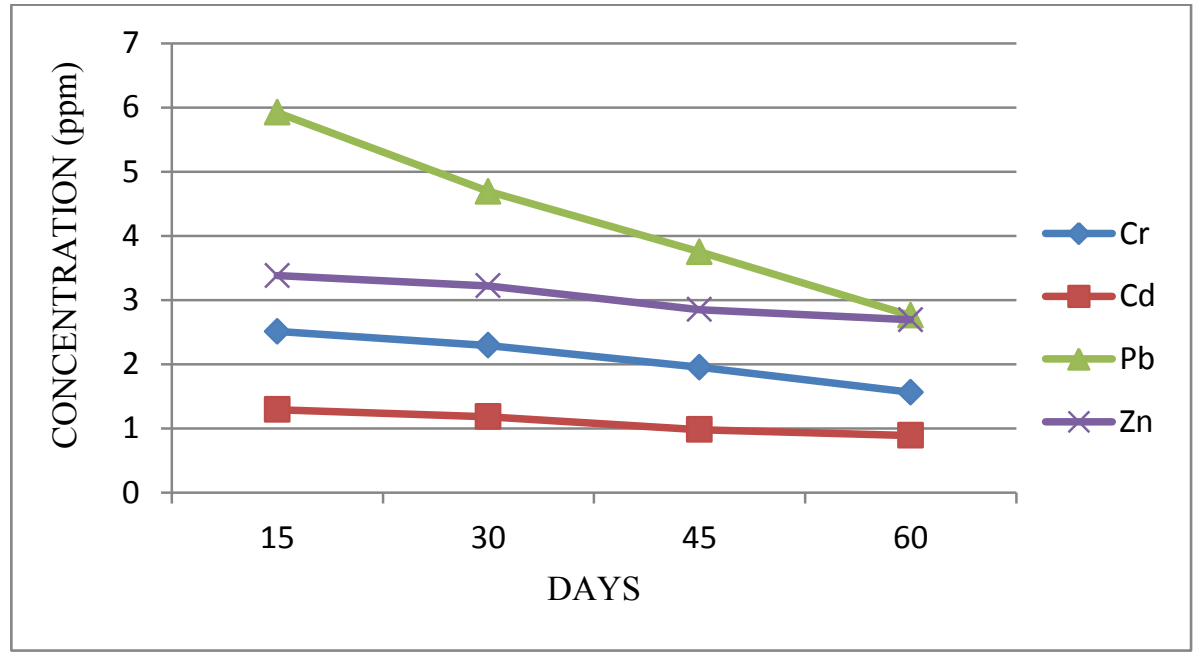

Fig. 3. Reduction of heavy metal concentrations in pot $\mathrm{C} 1$ to $\mathrm{C} 4$. 


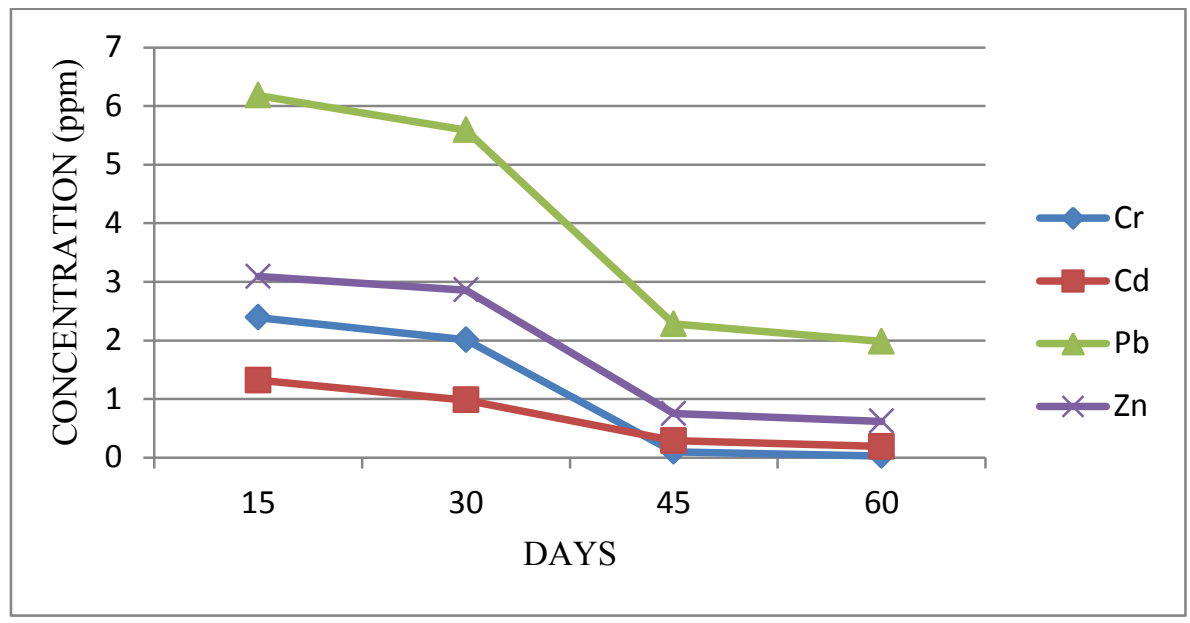

Fig. 4. Reduction of heavy metal concentrations in pot D1 to D4.

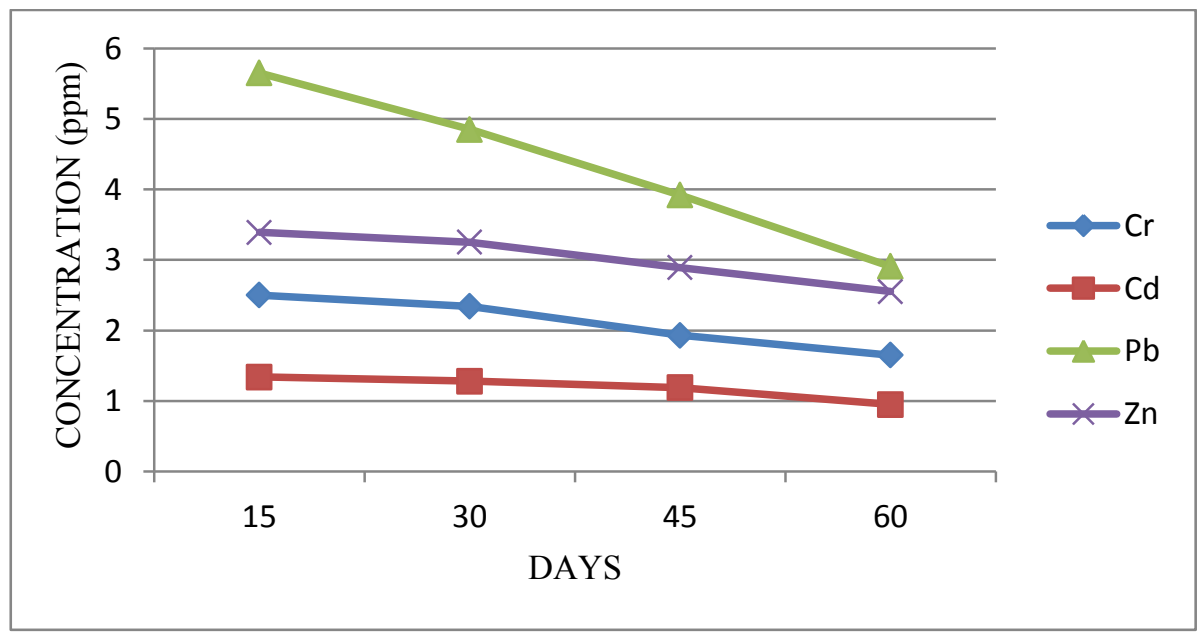

Fig. 5. Reduction of heavy metal concentrations in pot E1 to E4.

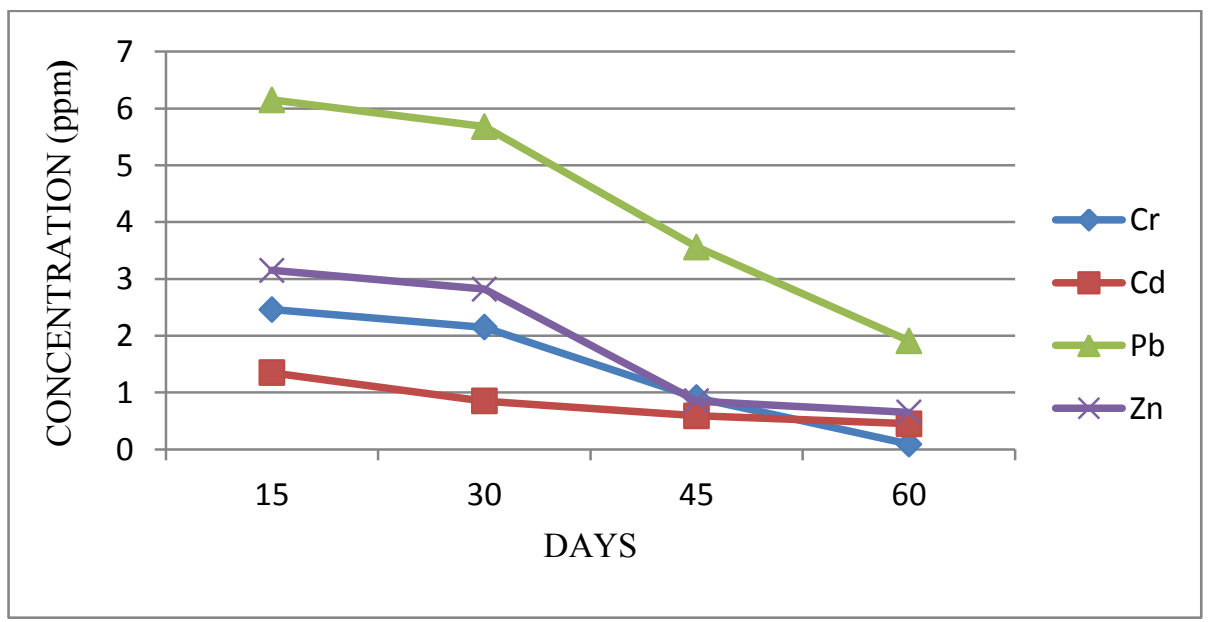

Fig. 6. Reduction of heavy metal concentrations in pot F1 to F4. 


\section{CONCLUSION}

The results indicated that the concentration of heavy metals are gradually decreases in vermicompost with garden soil combination. So, it is suitable for well growing plant and heavy metals accumulation (15-60 days). Other pots (A, C and E type) are not suitable for the removal of heavy metals in contaminated soil, because it decreases heavy metals slowly than above type of combination. This study shows that Croton sparsiflorus has a good potential to uptake and accumulate the toxic heavy metals from paper mill polluted soil. It also pares away for the development of an economically cheap technology and suitable for a good phytoremediation method.

\section{References}

[1] S.K. Rahman, D. Khanam, T.M. Adyel, M.S. Islam, M.A. Ahsan, M.A. Akbar, Applied Sciences 2(3) (2012) 584-601.

[2] K.P. Singh, D. Mohan, S. Sinha, R. Dalwani, Chemosphere 55 (2) (2004) 227-255.

[3] A.K. Chopra, S. Srivastava, V. Kumar, C. Pathak, Environmental Monitoring and Assessment 85 (8) (2013) 6635-6644.

[4] M.S. Fazeli, F. Khosravan, M. Hossini, S. Sathyaranayanan, P.N. Sathish, Journal of Environmental Geology 34 (4) (1998) 297-302.

[5] W.H. Liu, J.Z. Zhao, Z.Y. Ouyang, L. Soderland, G.H. Liu, Environmental International 31(6) (2005) 805-812.

[6] A.K. Chopra, C. Pathok, G. Prasad, Journal of Applied And Natural Science 1(1) (2009) 99-108.

[7] K. Fytians, G. Katsianis, G. Katsians, P. Triantaflllou, G.Zachariadis, Bulletin of Environmental Contamination and Toxicology 67(3) (2001) 423-430.

[8] N.K. Tandi, J. Nyamangara, C. Bangira, Journal of Environmental Science and Health 39(3) (2005) 461-471.

[9] C. Pathak, A.K. Chopra, S.Srivastava, Journal of Applied and Natural Science 4(2) (2012) 291-296.

[10] C. Pathak, A.K. Chopra, S. Srivastava, Environmental Monitoring and Assement, 2013.

[11] D. Sub, G. Mahajan, M.P. Kaur, Biores. Techroe. 99(14) (2008) 6017-6027.

[12] V. Kumar, A.K. Chopra, Communication in Soil Science and Plant Analysis 43(6) (2012) 2142-2166.

[13] L. Malla, B.K. Mohanty, Journal of Environmental Biology 26(2) (2005) 379-382.

[14] F. Mapanda, E.N. Mangwayan, J. Nyamangara, K.E. Giller, Agriculture Ecosystem and Environment 107(2-3) (2005) 151-165

[15] V. Kumar, "Effect of Industrial Effluent Irrigation on Agronomical Characteristics of Two Leguminous Crops, Phaseolus vulgaris (L) and Vigna radiate (L)", Ph.D Thesis, Gurukula Kangri University, Haridwar, 2010.

[16] H. Belorai, J. Levy, Israel J. Agric. Res. 21(1) (1971) 3-12. 
[17] Y. Waisel Academic press, New York, (1972) 345.

[18] S.N. Liss, P.A. Bicho, J.N. Saddler, Can. J. Microbial. 75 (1997) 599-611.

[19] E.A. Pilen-Smits, M.P. Desouza, G. Hong, A. Amini, R. Bravo, S.T. Payabyab, N. Terry, Journal of Environmental Quality 20 (1999) 1011-1017.

[20] A.J.M. Baker, S.M. Whiting, New phytologist 155 (2002) 1-7.

[21] S.D. Cunningham, W.R. Berti, Invitro Cell Dev. Biol. (1993) 207-212. 